Table 1. Epfecti of HeParin on the Esterase ACtivity of SERUM

\begin{tabular}{|c|c|c|c|}
\hline $\begin{array}{c}\text { Case } \\
\text { No. }\end{array}$ & Diagnosis & $\begin{array}{l}\text { Esterase act- } \\
\text { ivity (ml. } 0 \cdot 05 \\
N \text { sodium } \\
\text { hydroxide) }\end{array}$ & $\begin{array}{l}\text { Rise of ester- } \\
\text { ase activity } \\
\text { after heparin } \\
\text { injection } \\
\text { (per cent) }\end{array}$ \\
\hline $\begin{array}{l}1 \\
2 \\
3 \\
4 \\
\\
5 \\
6 \\
7\end{array}$ & $\begin{array}{l}\text { Bronchiogenic carcinoma } \\
\text { Carcinoma of the stomach } \\
\text { Carcinoma of the stomach } \\
\text { Adenocarcinoma of the } \\
\text { kidney } \\
\text { Bronchiogenic carcinoma } \\
\text { Bronchiogenic carcinoma } \\
\text { Bronchiogenic carcinoma } \\
\text { Average in } 25 \text { controls }\end{array}$ & $\begin{array}{l}0 \cdot 42 \\
0 \cdot 44 \\
0 \cdot 78 \\
1 \cdot 40 \\
1 \cdot 46 \\
2 \cdot 08 \\
1 \cdot 66 \\
3 \cdot 16\end{array}$ & $\begin{array}{r}780 \\
259 \\
203 \\
\\
113 \\
95 \\
93 \\
81 \\
35\end{array}$ \\
\hline
\end{tabular}

after administration of heparin. Five minutes after intravenous injection of heparin in amounts of 100 units per $\mathrm{kgm}$. body-weight, the increase reached as much as 780 per cent (Table 1).

This increase is much greater than in normal persons, in whom esterase activity has an average value of $3.16 \mathrm{ml}$. $0.05 \mathrm{~N}$ sodium hydroxide ${ }^{5}$ with a dispersion of $2 \cdot 00-4 \cdot 85$, by our method. There is a definite increase after administration of heparin in normal persons ${ }^{6}$, but it rarely exceeds 70 per cent and we found no increase greater than 100 per cent.

No explanation can at present be given for the great increase of the pathologically low values of esterase in carcinoma. There are, however, the following possibilities: (1) that there is an esterase inhibitor in the blood of the patients which is inactivated by heparin ; (2) that heparin washes out from the tissues into the blood stream an esterase which, in carcinoma, is not, or is only partly, damaged and which is able to break down ethyl butyrate.

J. SKOREPA

S. NovÁK

H. TODOROVIČovA

Fourth Medical Clinic,

Charles University,

Prague.

Dec. 20.

1 Maier, E. H., Dtsch. Med. Wschr., 81, 1674 (1956). Williams, H. M. LaMotta, R. V., and Wetstone, H. J., Gastroenterology, 33, 58 LaMott.

"Lagerlof, H., Acta Med. Scand., 120, 407 (1945).

' Czyzyk, A., Z. inn. Med. (Leipzig), 11, 1085 (1956).

‘Cherry, I. S., and Crandall, L. A., A mer. J. Physiol., 100, 268 (1932).

'Skotepa, Todorovičová, H., and Novák, S., Clin. Chim. Acta, \&, 157 (i957)

- Skơepa, J., and Todorovicová, H., Paper delivered at the 15th Regular Meeting Czech Medi

\section{Effect of a Lethal Electric Shock during Hypothermia}

IN our experiments we applied direct current at $220 \mathrm{~V}$., or alternating current, through a resistance with which the potential could be varied between 10 and $220 \mathrm{~V}$. The current passing through the animals was registered by milliammeter. Copper electrodes were attached to the forelegs of mice weighing 20-25 gm., the shaved limbs of which had been moistened by a solution of sodium chloride. The mice were cooled by Giaja's method. The temperature of the colon was registered by a thermistor thermometer.

Table 1 summarizes our results, from which it can be seen that hypothermia has a protective action. Increasing the potential enabled the hypothermic animsls to withstand a higher current. We found that with a direct current hypothermic animals with- stood a current lethal for controls at only $150 \mathrm{~V}$.; whereas with alternating current, the lethal current. was obtained at a potential of $120 \mathrm{~V}$. Histological examination of the mice which were killed by the electric current revealed no essential or characteristic changes in the nervous system or in the heart.

Table 1. EFFect of Electric SHOCK ON Normal AND ON HYPo-

\begin{tabular}{|c|c|c|c|}
\hline \multicolumn{1}{|c|}{ THERMIC MICE } \\
\hline Current & $\begin{array}{c}\text { Colonic } \\
\text { temperature }\end{array}$ & $\begin{array}{c}\text { Current passed } \\
\text { through the } \\
\text { animals } \\
\text { (mean value) }\end{array}$ & $\begin{array}{c}\text { Dead/ } \\
\text { shocked }\end{array}$ \\
\hline Direct current & $37-39^{\circ} \mathrm{C}$. & 62 m.amp. o & $46 / 50$ \\
(80 V.; 10 sec.) & $37-39^{\circ} \mathrm{C}$. & 100 m.amp. & $48 / 50$ \\
& $15-20^{\circ} \mathrm{C}$. & 40 m.amp. & $1 / 50$ \\
Alternating current & $15-20^{\circ} \mathrm{C}$. & 56 m.amp. & $3 / 50$ \\
(80 V.; 10 sec.) & $37-39^{\circ} \mathrm{C}$. & 100 m.amp. & $50 / 50$ \\
& $37-39^{\circ} \mathrm{C}$. & 118 m.amp. & $50 / 50$ \\
& $15-20^{\circ} \mathrm{C}$. & 40 m.amp. & $1 / 50$ \\
& $15-20^{\circ} \mathrm{C}$. & 55 m.amp. & $2 / 50$ \\
\hline
\end{tabular}

The conductivity of males under normal conditions: is $7.8 \times 10^{-4} \mathrm{ohm}^{-1}$; in a hypothermic state it is $5 \times 10^{-4} \mathrm{ohm}^{-1}$ (decrease, 36 per cent). The conductivity of control female mice is $12.5 \times 10^{-4} \mathrm{ohm}^{-1}$, that of cooled females $7 \times 10^{-4} \mathrm{ohm}^{-1}$ (decrease, 44.1 per cent). Putting the mean temperature of mice as $20^{\circ} \mathrm{C}$., the thermal coefficient of male mice is 1.86 per cent/degree, that of female mice is 2.2 per cent/degree, which corresponds very well with the thermal coefficient of ion activity. Therefore the main reason for the decrease in conductivity is probably the change of ion activity with temperature.

Full details of this work will be published in Acta Physiol. Hungarica.
T. SzHÁayi
K. BENKO
H. Csernyánszky

Institute of Pathophysiology, and

Institute of Physics,

Medical University,

Debrecen, Hungary. Sept. 7.

\section{Effect of Muscular Activity prior to Venepuncture on the Respiration of Leucocytes in vitro}

DURING an investigation of the respiration of human leucocytes we noticed that moderate exercise by the donor prior to venepuncture seemed to be associated with a high rate of leucocyte oxygen consumption. Determination of the oxygen consumption of leucocytes (resuspended in a modified Krebs No. 2 buffer) was made by the direct method in Warburg respirometers at $37^{\circ} \mathrm{C}$. Results were expressed as $\mu$ moles oxygen consumed per hr. per $10^{7}$ leucocytes, so that the effect of any variation in total white cell count was eliminated.

We therefore compared the oxygen consumption of white blood cells taken before and after exercise from six normal subjects. All were members of the clinical or laboratory staff, aged 18-29 years. The subjects were fasting, and had rested on a bed for $30 \mathrm{~min}$. before the first blood sample was obtained by venepuncture. A moderate walking exercise lasting 3-4 min. was then performed. Leucocytes obtained by venepuncture 5 min. after the walking exercise showed increased oxygen consumption 36-71 per cent above the control value before exercise (Table 1). Estimations of the subjects' oxygen consumption 